\title{
Deteksi Bakteri Klebsiella pneumonia pada Beberapa jenis Rokok Konsumsi Masyarakat
}

\author{
Dewi Elfidasari", Nita Noriko, Anita Mirasaraswati, Aishah Feroza, Siti Fauziah Canadianti \\ Program Studi Teknik Biologi, Fakultas Sains dan Teknologi, \\ Universitas Al Azhar Indonesia, Jl. Sisingamangaraja, Jakarta 12110 \\ *Penulis untuk korespondensi: d_elfidasari@uai.ac.id
}

\begin{abstract}
Abstrak - Rokok dinilai sebagai material yang banyak memberikan dampak yang merugikan bagi kesehatan, yang di mana komposisinya memberikan berbagai reaksi negatif dalam tubuh. Himbauan mengenai bahaya merokok yang diakibatkan oleh berbagai senyawa kimia banyak dipublikasikan pada masyarakat, namun dalam hal ini kesempatan muncul untuk mengungkapkan sisi lain dari rokok, yaitu melalui isolasi dan identifikasi bakteri yang terdapat pada tembakau dan abu rokok. Dengan melakukan isolasi dan identifikasi bakteri pada 6 sampel rokok yang telah ditentukan telah ditemukan 28 jenis bakteri yang tumbuh pada pengkulturan sampel tembakau, 14 jenis bakteri pada sampel abu rokok dengan 10 jenis bakteri tersebut dijumpai pula pada sampel rokok dan 4 diantaranya merupakan bakteri jenis lain yang hanya tumbuh pada sampel abu rokok.
\end{abstract}

Abstract - Cigarettes are also valued as a unhealthy product that can gain disadvantages impact, which in its composition provides variety of negative reaction to our body. Appealance about the dangers of smoking which caused by a variety of chemical compounds that widely publicized in the community, and this research can arises the opportunity to express the other side of the cigarette by isolation and identification the bacteria in tobacco and cigarette ash. The result analysis from isolation and identification of bacteria on 6 samples of cigarettes, it have been determined that 28 types of bacteria that have been found growed on cultured tobbaco samples, 14 different colonies of bacteria in cigarette ash samples with 10 types of bacteria that have the same type with the tobacco samples and 4 others which found grow only on the ash sample.
Keywords - cigarettes, bacteria, Nicotianae tabacum, ash, identification

\section{PENDAHULUAN}

$\mathrm{T}$ embakau atau Nicotianae tabacum L merupakan jenis tanaman herbal yang memiliki kumpulan zat-zat dengan beberapa efek farmakologi yang disebabkan oleh komposisi kandungan yang terdapat dalam tanaman tersebut bersifat konstruktif yaitu, bersifat membangun organ, sel dan sistem tubuh yang banyak digunakan sebagai salah satu bahan dasar dalam pembuatan rokok selain cengkeh dan bahan-bahan lainnya.

Menurut Framework Convention on Tobacco Control atau "FCTC"-WHO, produk tembakau adalah produk yang dibuat dengan menggunakan seluruh atau sebagian dari daun tembakau sebagai bahan dasar yang diproduksi dan digunakan sebagai rokok yang dikonsumsi dengan cara dihisap, dikunyah, atau dihirup. Produk tembakau banyak diproduksi sebagai rokok dalam bentuk sigaret, kretek, cerutu, lintingan, menggunakan pipa, tembakau yang dihisap, dan tembakau tanpa asap. [1]

Konsumsi tembakau di Indonesia yang kian marak hingga dikalangan anak-anak menimbulkan berbagai kekhawatiran terutama pada kesehatan pernapasan dan gejala lain yang ditimbulkan dari konsumsi rokok. Dengan banyaknya jumlah bahan kimia berbahaya yang terkandung dalam rokok ataupun yang terakumulasi dalam pembakaran tidak hanya dapat merugikan bagi perokok itu sendiri (perokok aktif) maupun orang lain yang menghirup asap rokok (perokok pasif).

Kini tidak hanya bahan kimia berbahaya yang menjadi kekhawatiran utama namun penelitian 
mengenai keterdapatan bakteri pathogen di dalam tembakau rokok juga dapat membahayakan bagi kesehatan, terutama pada perokok pasif.

Sebuah studi mengenai bahaya bakteri patogen pada rokok oleh tim internasional yang beranggotakan ilmuwan Kanada dan Prancis mengungkap bahwa beberapa jenis bakteri diketahui sebagai penyebab penyakit pada manusia terdapat pada sebatang rokok

Riset yang dilakukan tim peneliti kesehatan lingkungan dari University of Maryland, Amerika Serikat, dan ahli ekologi mikroba di Ecole Centrale de Lyon di Prancis itu adalah studi pertama yang memperlihatkan bahwa tanpa kandungan zat kimia berbahaya pun rokok sudah berbahaya [2]. Human pathogens abundant in the bacterial metagenome of cigarettes. Environ Health Perspect.

Konsumsi tembakau di Indonesia yang kian marak hingga dikalangan anak-anak menimbulkan berbagai kekhawatiran terutama pada kesehatan pernapasan dan gejala lain yang ditimbulkan dari konsumsi rokok. Dengan banyaknya jumlah bahan kimia berbahaya yang terkandung dalam rokok ataupun yang terakumulasi dalam pembakaran tidak hanya dapat merugikan bagi perokok itu sendiri (perokok aktif) maupun orang lain yang menghirup asap rokok (perokok pasif).

Namun, para ilmuan berpendapat, bahwa penelitian tersebut baru merupakan langkah awal sebagai tahap identifikasi bakteri patogen yang terdapat pada sebatang rokok yang diambil sampelnya secara acak. Pada Penelitian sebelumnya telah dilakukan dengan mengambil sedikit sampel tembakau dan menaruhnya dalam media kultur untuk melihat apakah bakteri tersebut dapat tumbuh.

Hasil penelitian yang telah dilakukan tersebut menjadi informasi bahwa pada rokok tidak hanya terdapat kandungan kimia berbahaya namun berhasil dideteksi keberadaan beberapa bakteri patogen yang dapat memberikan dampak yang buruk bagi kesehatan. Beberapa bakteri dapat menganggu beberapa sistem organ dalam tubuh manusia terutama pada pernapasan seperti halnya bakteri Klebsiella pneumonia yang merupakan bakteri patogen penyebab gangguan pernapasan [2]. Human pathogens abundant in the bacterial metagenome of cigarettes. Environt Health Perspect.
Untuk itu kami melakukan pengujian terhadap tembakau yang banyak dipasarkan di Indonesia dan melakukan identifikasi bakteri Klebsiella pneumonia yang kemungkinan terdapat dalam tembakau yang terkandung dalam sebatang rokok.

Informasi keberadaan bakteri tersebut dapat dijadikan sebagai indikator secara mikrobial akan bahaya rokok selain dari bahan kimia berbahaya yang sudah pasti terdapat pada rokok dalam bentuk tembakau maupun akumulasi senyawa berbahaya lainnya pada saat pembakaran.

\section{TINJAUAN PUSTAKA}

Tembakau (Nicotianae tabacum L) merupakan tanaman herbal yang termasuk dalam familia Solanaceae, dimana family ini memiliki banyak keuntungan bagi manusia. Spesies tembakau yang memilki banyak nilai ekonomis antara lain Nicotianae Tabocum L dan Nicotianae Rustica. [Direktorat Jendral Perkebunan, Departemen Kehutanan. Komoditas Tembakau] [3]

Perbedaan kedua jenis tembakau meliputi, Nicotiana rustica $L$ mengandung kadar nikotin yang tinggi $(\max \mathrm{n}=16 \%)$ biasanya digunakan untuk membuat abstrak alkoloid (sebagai bahan baku obat dan insektisida), jenis ini banyak berkembang di Rusia dan India. Sedangkan $N$. tabacum $\mathrm{L}$ mengandung kadar nikotin yang rendah $(\min \mathrm{n}=0,6 \%)$ jenis ini umumnya digunakan sebagai bahan baku pembuatan rokok. Namun Indonesia sendiri memiliki berbagai jenis tanaman bakau yang memiliki berbagai ciri khas di setiap daerah tanam sehingga sering dinamai dengan darimana asal tanaman bakau tersebut [Direktorat Jendral Perkebunan, Departemen Kehutanan. Komoditas Tembakau] [3]

Secara taksonomi, tembakau termasuk dalam Kelas Magnoliopsida, Ordo Solanales, Famili Solanaceae dan Genus Nicotiana [4].

Rokok memiliki banyak kandungan bahan kimia yang berbahaya bagi kesehatan tubuh. Menurut Organisasi Kesehatan Dunia (WHO), lingkungan asap rokok adalah penyebab berbagai penyakit, dan juga dapat dampak bagi orang sehat yang bukan perokok.

Paparan asap rokok yang dialami terus-menerus pada orang dewasa yang sehat dapat menambah resiko terkena penyakit paru-paru dan penyakit 
jantung sebesar 20-30\% . Lingkungan asap rokok dapat memperburuk kondisi seseorang yang mengidap penyakit asma, menyebabkan bronkitis, dan pneumonia [5].

Asap rokok juga menyebabkan iritasi mata dan saluran hidung bagi orang yang berada di sekitarnya. Pengaruh lingkungan asap tembakau dan kebiasaan ibu hamil merokok dapat menyebabkan gangguan kesehatan pada anaknya bahkan sebelum anak dilahirkan. Bayi yang lahir dari wanita yang merokok selama hamil dan bayi yang hidup di lingkungan asap rokok mempunyai resiko kematian yang sama [5].

Tingginya populasi dan konsumsi rokok menempatkan Indonesia menduduki urutan ke-5 konsumsi tembakau tertinggi di dunia setelah China, Amerika Serikat, Rusia dan Jepang dengan perkiraan konsumsi 220 milyar batang pada tahun 2005. Rokok juga mengandung lebih dari empat ribu bahan kimia, termasuk 43 bahan penyebab kanker yang telah diketahui, sehingga lingkungan yang terpapar dengan asap tembakau juga dapat menyebabkan bahaya kesehatan yang serius (Mentri Kesehatan Republik Indonesia) [5].

Konsumsi rokok di Indonesia memiliki tingkat konsumsi yang tinggi pada usia remaja antara 1315 tahun di tahun 2004 hingga 2006 beberapa kota besar di Indonesia [6].

Klebsiella pneumonia pertama kali diteliti dan diidentifikasi oleh bakteriologis Jerman bernama Edwin Klebs (1834-1913). Klebsiella pneumonia terdapat dalam feses dan saluran napas sebanyak $5 \%$ pada orang normal. Klebsiella pneumonia merupakan salah satu bakteri gram negative, bakteri yang non motil (tidak melakukan pergerakan secara sel), merupakan bakteri fakultatif an aerob, bakteri ini dapat memfermentasikan laktosa. Klebsiella pneumonia dapat menyebabkan pneumonia [7].

Pneumonia adalah proses infeksi akut yang mengenai jaringan paru-paru (alveoli). Pneumonia yang disebabkan oleh Klebsiella pneumonia dapat berupa pneumonia komuniti (community acquired pneumonia). Klebsiella pneumoniae merupakan jenis bakteri golongan Klebsiella yang banyak menginfeksi manusia. Merupakan organisme oportunis yang ditemukan pada lapisan mukosa mamalia, terutama paru-paru. Memiliki penyebaran yang sangat cepat, terutama di antara orang-orang yang sedang terinfeksi bakteri ini dengan gejala berupa pendarahan dan penebalan lapisan mukosa organ. Bakteri ini juga merupakan salah satu bakteri yang menyebabkan penyakit bronchitis [8].

Berdasarkan pembagian jenis rokok tersebut maka dapat dilihat bahwa jenis rokok yang banyak beredar di pasar antara lain jenis rokok sigaret dengan pembungkus kertas, yang dibuat dengan mesin yaitu sigaret mesin dan merupakan rokok filter dan non-filter

\section{METODE PENELITIAN}

\subsection{Objek Penelitian dan lokasi penelitian}

Objek penelitian adalah sampel rokok yang diperoleh dari beberapa penjaja rokok, terdapat enam merek dagang yang diuji untuk deteksi bakteri. Merek tersebut meliputi DJS,MRL, GGF, DS, ENV, SMP-M, Selanjutnya sampel dianalisa di Laboratorium Mikrobiologi Universitas Al Azhar Indonesia.

\subsection{Metode analisa sampel}

Analisa koloni bakteri dilakukan terhadap tembakau dan abu yang dihasilkan dari rokok yang telah dibakar sebagai sampel dari satu merek rokok. Masing-masing dari sample, ditimbang sebanyak 1gr untuk kemudian diencerkan dengan menggunakan air pepton yang telah diencerkan sebanyak $9 \mathrm{ml}$.

Tiap sampel pengenceran diambil $0,1 \mathrm{ml}$ dan kemudian dikultur pada media biakan agar selektif bakteri gram negatif (McConkey Agar dan EMB Agar) dengan tujuan seleksi bakteri gram negatif dan positif dapat teridentifikasi pertumbuhannya melalu seleksi media agar. Masing-masing sample diambil ulangannya sebanyak 16 kali.

Bakteri yang telah dikultur kemudian diinkubasi pada suhu $30-25^{\circ} \mathrm{C}$ yang merupakan suhu optimal bagi pertumbuhan bakteri gram negatif. Pengamatan pertumbuhan diamati selama kurang lebih 24-48 jam dimana hal tersebut merupakan fase optimum pertumbuhan bakteri. Dilakukan pencatatan data hasil pengamatan.

Setiap periode pengkulturan sample diamati dengan melihat ada tidaknya koloni bakteri dan koloni diklasifikasikan berdasarkan bentuk dan ukurannya. 


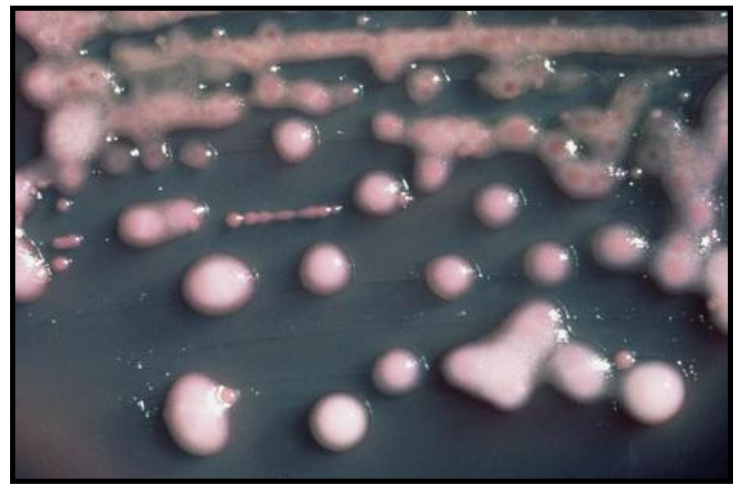

Gambar 1. Morfologi bakteri Klebsiella pneumonia

Data yang telah diperoleh dari tiap pengkulturan yang dilakukan dikumpulkan dan dicatat hingga akhirnya jenis merek rokok mana yang memiliki kandungan bakteri Klebsiella pneumonia.

Indikasi keberadaan bakteri Klebsiella pneumonia ditunjukkan dengan adanya pertumbuhan koloni bakteri pada tiap sample yang dikulturkan. (Gambar 1). Metode yang digunakan untuk melakukan pengolahan data identifikasi jumlah koloni bakteri yang terdapat pada cawan biakan adalah Metode Standard Plate Count (SPC) pada media Nutrient Agar (NA).

\section{HASIL DAN PEMBAHASAN}

Hasil kultur bakteri yang berasal dari enam sampel rokok berupa tembakau dan abu yang ditumbuhkan pada media EMB menunjukan hasil yang bervariasi. Penggunaan media EMB adalah untuk membuktikan keberadaan bakteri-bakteri yang besifat pathogen pada sampel rokok yang diuji.

Media agar EMB (Eosine Methilen Blue) sebagai media perkembangbiakan yang cukup ideal bagi bakteri gram negatif yang kemudian dapat membedakan warna koloni bakteri yang tumbuh pada cawan biakan, terutama pada koloni Escherichia coli yang dikhawatirkan menjadi bakteri utama yang sering kali tumbuh pada sampel yang terindikasi terkena cemaran. [7][9]

Media EMB merupakan media selektif yang digunakan untuk pertumbuhan bakteri gram negatif. Media ini mengandung eosine dan methilen blue yang dapat berfungsi dalam membedakan koloni yang tumbuh pada media tersebut dengan memberikan warna hijau mengkilat yang disebabkan oleh Kristal violet yang terkandung dalam media sehingga dengan mudah dapat membedakan pertumbuhan Escherechia coli yang dikhawatirkan sebagai bakteri kontaminan terbesar pada sampel [9].

Laktosa dan sukrosa yang terdapat dalam medium ini menyebabkan bakteri Salmonella dan Shigellalactose dan sucrose negatif dapat dibedakan dengan organisme coliform-lactose positive dan mikroflora lainnya yang bersifat lactose-negative dan sucrosepositive seperti Proteus vulgaris, Citrobacter, atau Aeromonas hydrophila. Pertumbuhan dari mikroorganisme lain yang sejenis, khususnya bakteri Gram-positif, dihambat dengan adanya dyes yang terdapat dalam medium [9].

Hasil pengujian sampel yang dilakukan terhadap sampel tembakau dan abu rokok dari enam merek rokok menunjukan tidak dijumpainya bakteri Klebsiella pneumonia pada semua sampel rokok yang diujikan. Akan tetapi analisa mikrobiologi terhadap enam merek sampel rokok secara keseluruhan memperlihatkan keberadaan 28 jenis bakteri pada sampel tembakau dan 14 jenis bakteri yang terdapat pada sampel abu rokok, dengan persentase koloni bakteri tertinggi yaitu bakteri A sebanyak 94\%, dan sisanya ialah koloni $\mathrm{U}, \mathrm{B}, \mathrm{C}, \mathrm{L}, \mathrm{M}, \mathrm{R}, \mathrm{T}, \mathrm{X}$ dimana persentasenya tidak lebih dari satu persen. (Gambar 2).

Berdasarkan perbedaan merek sampel rokok uji, terdapat variasi dalam perbedaan jenis dan jumlah bakteri yang dijumpai pada sampel tembakau dan abu rokok. Berikut merupakan grafik persentase jumlah bakteri yang terdapat pada sampel uji tembakau rokok dan abu rokok pada tiap sampel.

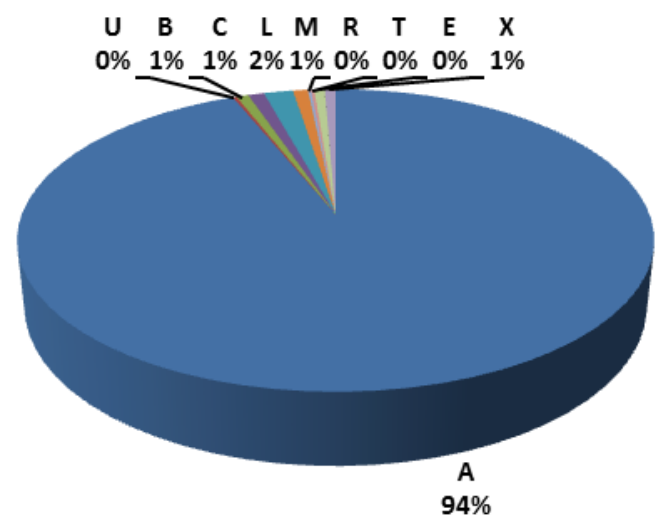

Gambar 2. Sepuluh koloni bakteri yang paling banyak terdapat pada sampel rokok 
Untuk rokok merek DJS, pada sampel tembakau dan abu rokok dijumpai sepuluh jenis bakteri yang berhasil diisolasi pada media agar EMB. Jenis bakteri A merupakan jenis bakteri dominan yang dijumpai dalam jumlah 94\%. Pada sampel tersebut ditumbuhi bakteri jenis A dengan jumlah 3838 selain itu grafik menunjukkan nilai pada bakteri jenis L dan C dengan jumlah 188 dan 51 sedangkan pada sampel abu, grafik jumlah bakteri yang teridentifikasi tidak memiliki perubahan jumlah yang signifikan. (Gambar 3).

Pada sampel rokok dengan merek MRL, perbandingan jumlah koloni bakteri yang dapat teridentifikasi dapat ditunjukkan berdasarkan perubahan bentuk grafik antara lain pada jenis bakteri A dengan jumlah koloni yang teridentifikasi pada sampel tembakau menunjukkan jumlah 234 koloni, bakteri jenis $\mathrm{M}$ dengan jumlah 115 koloni, bakteri R berjumlah 23 koloni, diikuti bakteri V,C, $\mathrm{B}$ dan $\mathrm{T}$ berjumlah $1,27,15$ dan 26. Sedangkan pada sampel abu, bakteri A terlihat memiliki jumlah yang tinggi, yakni berjumlah 300 koloni. (Gambar 4)

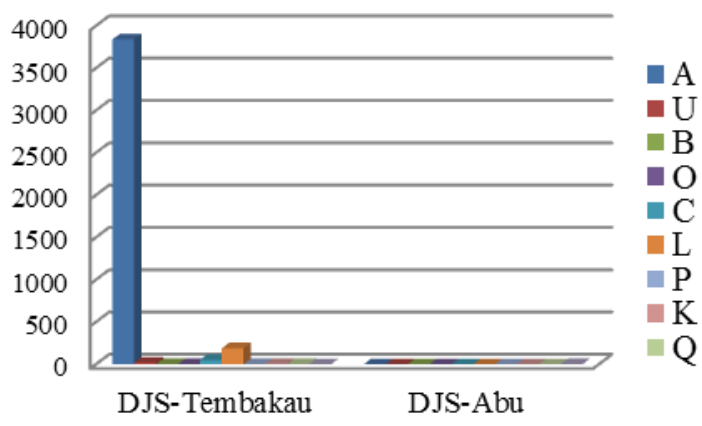

Gambar 3. Perbandingan jenis dan jumlah koloni bakteri pada sampel tembakau dan abu rokok merek DJS

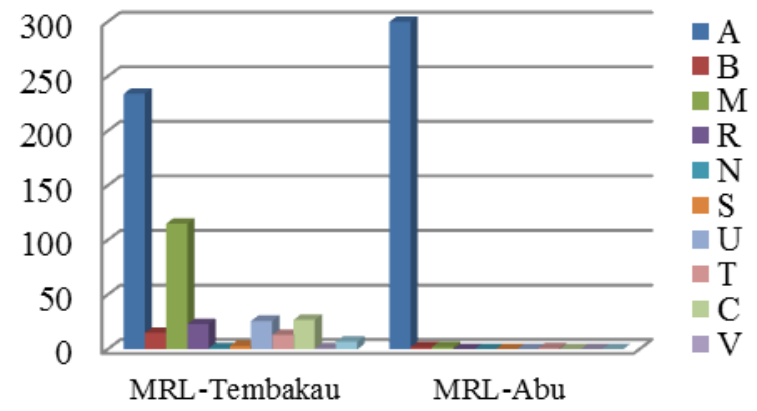

Gambar 4. Perbandingan jenis dan jumlah koloni bakteri pada sampel tembakau dan abu rokok merek MRL
Pada sampel rokok merek GGF, perbandingan jumlah koloni bakteri yang tumbuh pada sampel tembakau juga ditunjukkan berdasarkan perubahan grafik jumlah koloni bakteri pada bakteri jenis A yaitu sebanyak 2141 koloni dan dapat dilihat pada bakteri jenis E sebanyak 82 koloni sedangkan pada sampel tembakau bakteri jenis A memiliki jumlah 600 koloni namun tidak terlihat perubahan bentuk grafik pada bakteri jenis lain. (Gambar 5).

Pada sampel rokok dengan merek DS, perbandingan jumlah koloni yang tumbuh berdasarkan grafik pertumbuhan bakteri terlihat perubahan pada jenis bakteri A dengan jumlah mencapai 4620 koloni bakteri pada sampel tembakau, sedangkan pada sampel abu perubahan grafik jumlah tidak memiliki perubahan dalam jumlah yang besar. (Gambar 6)

Pada sampel rokok merek ENV, perbandingan jumah bakteri yang tumbuh juga terlihat pada bakteri jenis A dengan perubahan grafik pada tabel perbandingan jumlah koloni bakteri yaitu sebanyak 504 koloni bakteri dan pada bakteri jenis L dengan

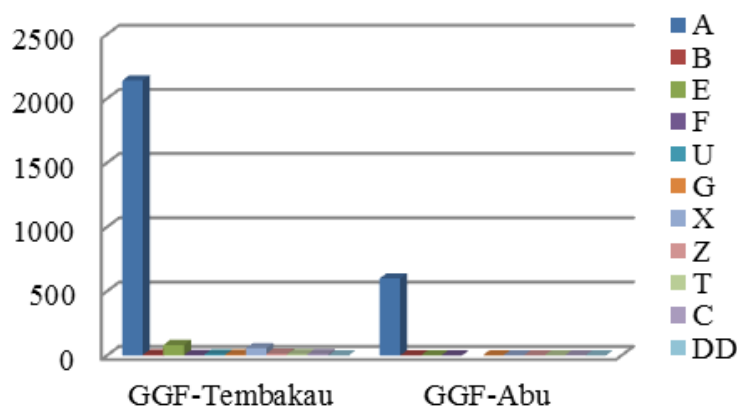

Gambar 5. Perbandingan jenis dan jumlah koloni bakteri pada sampel tembakau dan abu rokok merek GGF

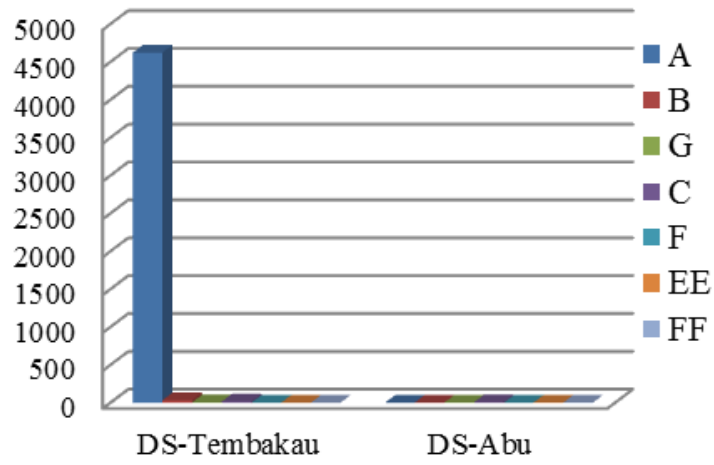

Gambar 6. Perbandingan jenis dan jumlah koloni bakteri pada sampel tembakau dan abu rokok merek DS 
jumlah bakteri mencapai 41 koloni. Sedangkan pada sampel abu, perubahan grafik tidak menunjukkan jumlah yang signifikan. (Gambar 7).

Pada sampel rokok terakhir yaitu sampel rokok merek SMP-M, jumlah koloni bakteri yang memiliki peningkatan jumlah koloni yang ditunjukkan berdasarkan perubahan grafik jumlah koloni bakteri yaitu terdapat pada bakteri jenis A dengan jumlah 846 koloni bakteri, kemudian pada jenis bakteri $\mathrm{J}$ memiliki jumlah 48 koloni bakteri sedangkan pada sampel abu, perubahan grafik jumlah tidak menunjukkan perubahan yang signifikan pada grafik. (Gambar 8).

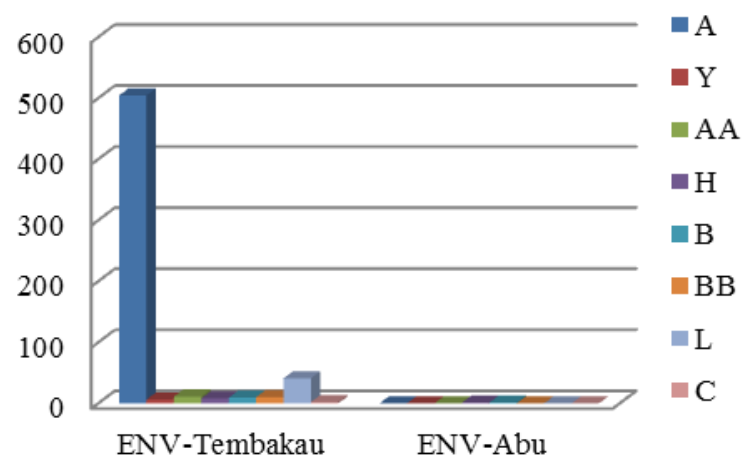

Gambar 7. Perbandingan jenis dan jumlah koloni bakteri pada sampel tembakau dan abu rokok merek ENV

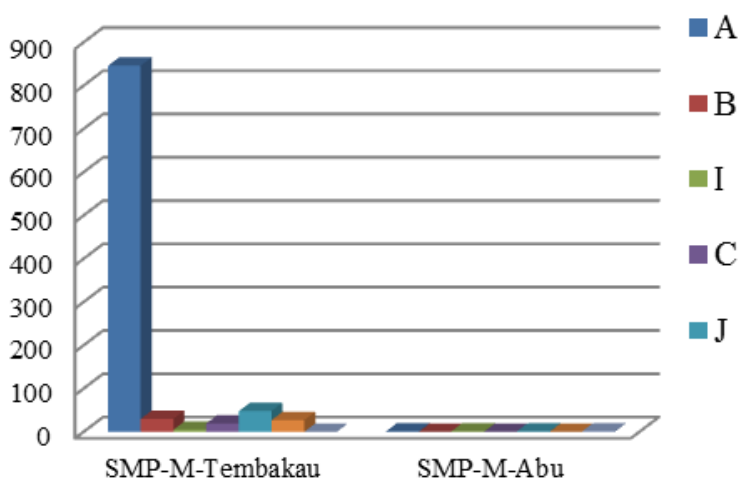

Gambar 8. Perbandingan jenis dan jumlah koloni bakteri pada sampel tembakau dan abu rokok merek SMP-M

\subsection{Identifikasi Bakteri Gram Negatif dan Gram Positif}

Dengan melihat hasil identifikasi secara makroskopis kemudian pengamatan dilakukan dengan mengamati bentuk morfologi secara mikroskopis yaitu, dengan menggunakan metode pewarnaan gram, kemudian hasil dari tiap pewarnaan dapat diamati pada mikroskop dengan menggunakan perbesaran 1000x.

Dari hasil identifikasi tersebut diperolehlah hasil bakteri dengan morfologi Bacillus pada keseluruhan bakteri yang dapat diamati (Gambar 9 dan 10). Berikut ini merupakan beberapa contoh hasil morfologi bakteri yang dapat diamati secara mikroskopis yang berasal dari 28 jenis bakteri yang teridentifikasi secara makroskopis pada morfologi koloni yang tumbuh pada cawan biakan.

Berdasarkan jurnal yang dipublikasikan oleh peneliti dari Maryland, Amerika Serikat yaitu Amy R. Sapkota, Sibel Berger, dan Timothy M. Vogel dalam jurnalnya yang berjudul "Human Pathogens Abundat in the Bacterial Metagenome of Cigarettes, bakteri yang dapat teridentifikasi dapat meliputi Acinetobacter, Bacillus, Burkholderia,Clostridium, Klebsiella oxytoca, Pseudomonas, termasuk Pseudomonas aeruginosa dan Pseudomonas stutzeri.

Jenis bakteri tersebut umumnya memiliki bentuk Bacillus, dengan demikian dapat dikatakan bahwa kemungkinan dari 28 jenis bakteri yang teramati memiliki kesamaaan jenis bakteri walaupun masih dibutuhkan penelitian lanjutan untuk dapat mengidentifikasi jenis bakteri tersebut.

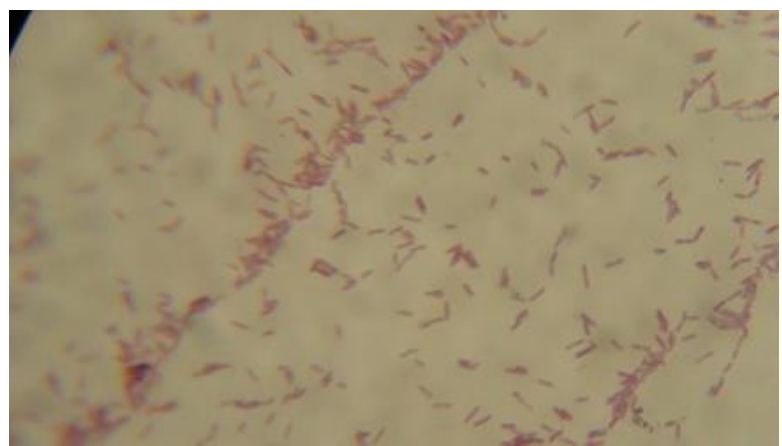

Gambar 9. Streptobacillus - gram Positif 


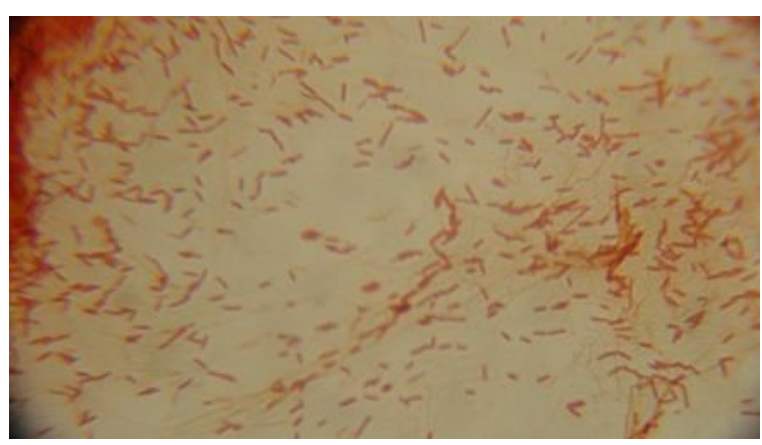

Gambar 10. Bacillus - Gram Positif

\section{KESIMPULAN}

Penelitian dilakukan pada enam sampel rokok yaitu DJS, GGF, DS, SMP-M, MRL dan ENV yang memperlihatkan adanya 28 koloni bakteri yang berbeda pada sampel tembakau dan 14 koloni yang berbeda pada sampel abu.

Koloni bakteri dengan jenis bakteri I merupakan bakteri dominan dalam setiap hasil pertumbukan bakteri untuk tiap sampel rokok. Namun keberadaan bakteri Klebsiella pneumonia yang dijadikan sebagai bakteri utama dalam identifikasi dan isolasi memberikan hasil negatif dalam pengujian.

\section{DAFTAR PUSTAKA}

[1] Ruth Roemer, JD, Allyn Taylor, JSD, JD, and Jean Lariviere, MD, .(2005). Framework Convention on Tobacco Control

[2] Sapkota AR, Berger S, Vogel TM. (2010). Human pathogens abundant in the bacterial metagenome of cigarettes. Environ Health Perspect

[3] Direktorat Jendral Perkebunan, Departemen Kehutanan. Komoditas Tembakau

[4] www.plantamor.com: Informasi spesies. Nicotianae tabacum $L$

[5] Kementrian Kesehatan Republik Indonesia. Rokok Membunuh Lima Juta Orang Setiap Tahun. (http://www.depkes.go.id/index.php/berita/pressrelease/458-rokok-membunuh-lima-juta-orangsetiap-tahun.html

[6] Strong, K. and Bonita, R. 2003. Curent Smoking Data from The Indonesia Health Survey (SUKERNAS). The SuRF Report 1. Surveillance of Risk Factors related to Noncommunicable Diseases: Current status of global data. Geneva: World Health Organization WHO]

[7] Center of Disease Control and Prevention (2009) Klebsiella pneumonia in Healthcare Setting

[8] Phage Therapy Center (2009) Klebsiela pneumonia

[9] Merck Microbiology Manual 12th Edition. EMB Agar (Eosine Methylene-Blue Lactose Sucrose Agar 